\title{
Aplikasi Sarana Prasarana Pendidikan Pada SMKN 4 Kota Bengkulu Menggunakan Pemrograman Visual Basic
}

\author{
Liza Yulianti ${ }^{1}$, Prahasti ${ }^{2}$, Venny Novita Sari ${ }^{3}$ \\ ${ }^{123}$ Dosen Tetap Program Studi Informatika Fakultas Ilmu Komputer Universitas Dehasen Bengkulu \\ Jln. Meranti Raya No.32 Kota Bengkulu 38228 Telp. (0736) 22027 Fax. (0736) 341139 \\ email : liza.yulianti@unived.ac.id, ${ }^{2}$ prahasti.mona82@gmail.com, ${ }^{3}$ vennynovita17@gmail.com
}

\begin{abstract}
Poor management of educational facilities and infrastructure can cause various problems, especially in documenting and managing assets in schools. Educational infrastructure is a school asset that must be properly organized and managed to support the assurance of the quality of education in schools. Utilization of information technology through programming languages can create various applications needed according to user needs. This study aims to make an application of educational facilities and infrastructure using the Visual Basic programming language and mySQL database. The system development method used is the System Development Lif Cycle (SDLC) or the waterfall approach. The research stages started from system design, system analysis, system design, program coding, program testing, system implementation and system maintenance. The result of the research is the application of educational facilities with spatial data reports, per-type sarpras reports, spatial sarpras reports and educational sarpras recapitulation. The application made is expected to improve services for the school for information on educational facilities so as to ensure the quality of education at public vocational high school 4 Bengkulu City.

Keywords: Educational Infrastructure, Programming Language, MySQL, Visual Basic.
\end{abstract}

Intisari:Pengelolaan sarana dan prasarana pendidikan yang kurang baik dapat menimbulkan berbagai permasalahan terutama dalam pendokumentasian dan pengelolaan aset yang ada di sekolah. Sarana prasarana pendidikan merupakan aset sekolah yang harus ditata dan dikelola dengan baik untuk mendukung terjaminnya kualitas pendidikan yang ada disekolah. Pemanfaatan teknologi informasi melalui bahasa pemrograman dapat menciptakan berbagai aplikasi yang dibutuhkan sesuai kebutuhan pengguna. Penelitian ini bertujuan untuk membuat aplikasi sarana dan prasana pendidikan dengan menggunakan bahasa pemrograman visual basic dan database mySQL. Metode pengembangan sistem yang digunakan adalah Sistem Development Lif Cycle (SDLC) atau pendekatan air terjun (waterfall). Tahapan penelitian dimulai dari perancangan sistem, analisis sistem, desain sistem, pengkodean program, uji coba program, impementasi sistem dan pemeliharaan sistem. Hasil penelitian adalah adanya aplikasi sarana prasarana pendidikan dengan laporan-laporan data ruang, laporan sarpras perjenis, laporan sarpras perruang dan rekapitulasi sarpras pendidikan. Aplikasi yang dibuat diharapkan dapat meningkatkan pelayanan bagi pihak sekolah akan informasi sarana prasana pendidikan sehingga dapat menjamin mutu pendidikan yang di SMKN 4 Kota Bengkulu.

Kata Kunci : Sarana Prasarana Pendidikan, Bahasa Pemrograman, MySQL, Visual Basic.

\section{PENDAHULUAN}

Pemanfaatan teknologi informasi sebagai pendukung peningkatan layanan akan akses informasi saat ini telah dimanfaatkan oleh berbagai pihak baik institusi pemerintahan maupun swasta. Bahasa pemrograman
Visual Basic sebagai salah satu bahasa pemrograman banyak saat ini dimanfaatkan dalam menciptakan berbagai aplikasi dalam mendukung kinerja orang-orang yang terlibat dalam dunia teknologi dan informasi. Secara umum, bahasa pemrograman visual basic merupakan suatu bahasa pemrograman berbasis Windows dengan konsep pemrograman berorientasi objek yang mengizinkan pengguna mengembangkan berbagai aplikasi dengan program event-driven untuk menciptkan berbagai aplikasi-aplikasi berbasis windows yang menarik.

SMKN 4 Kota Bengkulu sebagai salah satu lembaga pendidikan pada jenjang Sekolah Menengah Kejuruan (SMK) telah memiliki sarana dan prasarana pendidikan yang cukup lengkap. Sebagai sekolah kejuruan yang telah menerapkan manejemen mutu sebagai penjamin kualitas sekolah tentunya pengelolaan sarana dan prasana pendidikan yang ada di sekolah harus terdokumentasi dan tercatat dengan baik. Namun demikian, berdasarkan wawancara dengan staff sarana dan prasana SMKN 4 Kota Bengkulu, pengelolaan sarana dan prasarana yang ada di SMKN 4 Bengkulu belum memanfaatkan aplikasi khusus. Aktivitas tersebut dapat dilihat dari proses pendataan sarana dan prasarana dilakukan sarana dan prasarana yang ada saat ini masih dicatat kedalam lembaran format buku induk dengan menggunakan tulisan tangan. Selanjutnya buku induk tersebut disimpan dalam lemari arsip yang memungkinkan dapat rusak. Pengelolaan sarana dan prasarana yang ada memungkinkan pengarsipan yang kurang maksimal sehingga dibutuhkan suatu terobosan dalam membantu kinerja sekolah dalam mengelola sarana dan prasaran pendidikan supaya lebih baik dengan memanfaatkan aplikasi khusus berbasis teknologi informasi. 


\section{TINJUAN PUSTAKA}

\section{A. Pengertian Sarana Pendidikan}

Sarana Pendidikan adalah peralatan dan perlengkapan yang secara langsung digunakan dan menunjang proses Pendidikan, khususnya proses belajar mengajar seperti: Gedung, ruang kelas, meja kursi serta alat-alat dan media pengajaran" [1].

Ditinjau dari fungsi dan peranannya terhadap pelaksanaan proses belajar mengajar, maka sarana pendidikan dibedakan menjadi tiga macam yaitu: 1) alat pelajaran 2) alat peraga dan 3) media pengajaran [2].

\section{B. Pengertian Prasarana Pendidikan}

Prasarana Pendidikan adalah semua perangkat kelengkapan dasar yang secara tidak langsung menunjang pelaksanaan proses pendidikan di sekolah [3].

Prasarana Pendidikan adalah fasilitas yang secara tidak langsung menunjang jalannya proses pengajaran seperti: halaman, taman sekolah, jalan menuju sekolah [4].

Prasarana pendidikan bisa diklasifikasikan menjadi dua macam. Pertama, prasarana Pendidikan yang secara langsung digunakan untuk proses belajar mengajar, seperti ruang teori, ruang perpustakaan, ruang praktik keterampilan dan ruang laboratorium. Kedua, prasarana Pendidikan yang keberadaannya tidak digunakan untuk proses belajar mengajar, tetapi secara langsung sangat menunjang terjadinya proses belajar mengajar, seperti ruang kantor, kantin, masjid/mushola, tanah, jalan menuju Lembaga, kamar kecil, ruang usaha Kesehatan, ruang guru, ruang kepala sekolah dan tempat parkir kendaraan [5].

Berdasarkan pengertian tersebut diatas dapat disimpulkan bahwa prasarana pendidikan merupakan suatu fasilitas sekolah baik secara langsung maupun tidak langsung yang dapat digunakan dalam mendukung proses kegiatan belajar mengajar yang dapat dimanfaatkan oleh seluruh stakholder yang ada dalam lingkungan pendidikan.

\section{Pengertian Pemrograman}

Pemrograman adalah proses untuk menyelesaikan masalah dalam bentuk Langkah-langkah penyelesaian yang dapat dikerjakan oleh komputer (yang disebut algoritma) hingga ke penerjemahan kode dalam suatu bahasa pemrograman, sehingga masalah tersebut benarbenar bisa dieksekusi oleh komputer [6].

\section{Pengertian Visual Basic}

Visual Basic merupakan salah satu bahasa pemrograman visual. Dengan Visual Basic dengan mudah dapat membuat suatu program aplikasi. Untuk membangun sebuah aplikasi database dengan menggunakan Visual Basic dapat dilakukan dengan adanya kontrol ActiveX yang mudah digunakan [7].

E. Pengertian $M y S Q L$

MySQL merupakan tipe data relasional yang artinya MySQL menyimpan datanya dalam bentuk table-tabel yang saling berhubungan [8]. MySQL termasuk jenis RDBMS (Relational Database Management System).Pada MySQLsebuah database mengandung satu atau sejumlah tabel. Untuk menghubungkan database $M y S Q L$ dengan aplikasi Visual Basic diperlukan MyODBC. MyODBC adalah driver $O D B C$ untuk $M y S Q L$ yang dapat dijalankan dibanyak platform. $O D B C$ adalah singkatan dari Open Database Connectivity dan merupakan seperangkat fungsi yang memungkinkan melakukan koneksi database secara lokal maupun remote.

\section{F. Pengertian Data Flow Diagram}

Data Flow Diagram (DFD) adalah Suatu model logika data atau proses yang dibuat untuk menggambarkan darimana asal data dan kemana tujuan data yang keluar dari sistem, dimana data disimpan, proses apa yang menghasilkan datat tersebut dan interaksi antara data yang disimpan dan proses pada data [9].

\section{G. Pengertian Entity Relationship Diagram}

Entity Relationship Diagram (ERD) adalah "gambar atau diagram yang menunjukkan informasi dibuat, disimpan, dan digunakan dalam bisnis". Entity Relationship Diagram (ERD) dikembangkan berdasarkan teori himpunan dalam bidang matematika. ERD digunakan untuk pemodelan basis data relasional [10].

\section{METODELOGI PENELITIAN}

Metode Pengembangan system yang penulis gunakan yaitu metode SDLC (Sistem Development Life Cycle) atau metode pendekatan air terjun (waterfall). Metode ini 
diperkenalkan oleh W. Royce pada tahun 1970. Metode Waterfall merupakan metode klasik yang sederhana dengan aliran sistem yang linier output dari setiap tahap merupakan input bagi tahap berikutnya [10]. Adapun tahapan pengembangan sistem sebagai berikut:

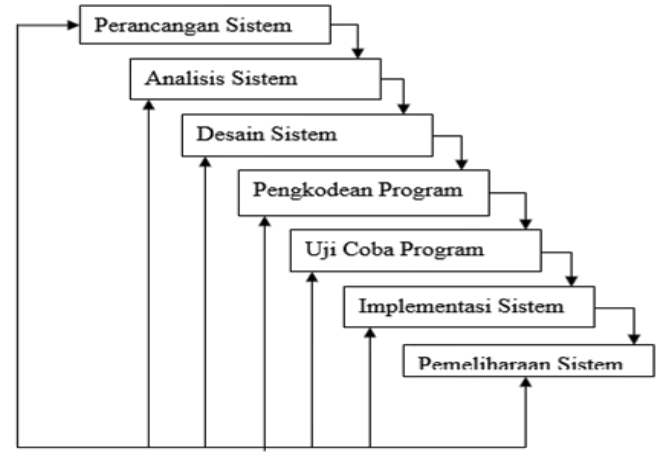

Gambar 1. Metode Waterfall

Metode pengumpulan data pada penelitian terdiri dari metode observasi, metode wawancara dan metode studi Pustaka. Metode observasi merupakan metode pengumpulan data yang digunakan dengan cara pengamatan yang bersifat sistematis secara langsung lokasi penelitian yang dituju yaitu mengenai hal-hal yang berkaitan dengan masalah yang di teliti pada SMKN 4 Kota Bengkulu. Metode wawancara dilakukan untuk mendapatkan gambaran tentang proses pengelolaan sarana dan prasaran pendidikan yang ada di SMKN 4 Kota Bengkulu. Penulis secara langsung melakukan wawancara dan tanya jawab langsung kepada Bapak Riwan,S.Pd selaku Wakil Kepala Sekolah bidang sarana dan prasana serta Ibu Siti Mashita selaku staff bidang sarana dan prasarana. Disampiang itu, untuk menambah literature tentang kepustakaan yang berkaitan dengan penelitian, metode pengumpulan data dilakukan melalui studi pustaka dengan mengambil informasi buku-buku yang berhubungan dengan penulisan, serta pencarian data-data dan informasi dari buku-buku dan bahan bacaan lain misalnya surat kabar, tabloid, majalah maupun internet.

\section{A. Rancangan Sistem Baru}

1) Diagram Konteks

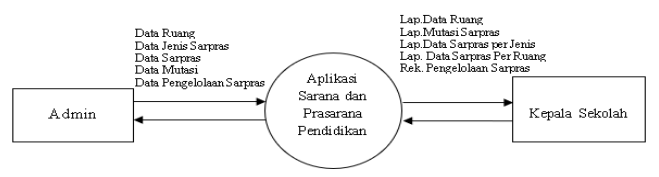

Gambar 1. Diagram Konteks 
B. Rancangan File Database DB_SARPRAS.

1) Tabel Data Ruang

Nama Tabel : Ruang

Primary Key : KdRuang

Tabel 1. Ruang

\begin{tabular}{|c|c|c|c|}
\hline $\begin{array}{l}\text { Nama } \\
\text { Field }\end{array}$ & Tipe & Lebar & Keterangan \\
\hline KdRuang & INT & 5 & Kode Ruang \\
\hline NmRuang & VARCHAR & 35 & Nama Ruang \\
\hline P_Jawab & VARCHAR & 35 & $\begin{array}{l}\text { Penanggung } \\
\text { Jawab }\end{array}$ \\
\hline
\end{tabular}

2) Tabel Jenis Sarpras

Nama Tabel : Jenis_Sarpras

Primary Key : KdJenis

Foreign Key : -

Tabel 2. Jenis Sarpras

\begin{tabular}{|l|c|c|l|}
\hline Nama Field & \multicolumn{1}{c|}{ Type } & \multicolumn{1}{c|}{ Lebar } & \multicolumn{1}{c|}{ Keterangan } \\
\hline KdJenis & INT & 5 & Kode Jenis \\
\hline JenisSarpras & $\begin{array}{c}\text { VARCH } \\
\text { AR }\end{array}$ & 35 & Jenis Sarpras \\
\hline Ket & $\begin{array}{c}\text { VARCH } \\
\text { AR }\end{array}$ & 35 & $\begin{array}{l}\text { Ket. Jenis } \\
\text { Sarpras }\end{array}$ \\
\hline \multicolumn{2}{|l}{} & \multicolumn{2}{|l}{} \\
\hline
\end{tabular}

3) Tabel Sarana dan Prasarana

Nama Tabel : Sarpras

Primary Key : KdSarpras

Foreign Key : KdJenis, KdRuang

Tabel 3. Sarpras

\begin{tabular}{|c|c|c|c|}
\hline Nama Field & Type & Lebar & Keterangan \\
\hline KdSarpras & INT & 5 & Kode Sarpras \\
\hline NmSarpras & $\begin{array}{c}\text { VARCH } \\
\text { AR }\end{array}$ & 35 & Nama Sarpras \\
\hline Deskripsi & $\begin{array}{c}\text { VARCH } \\
\text { AR }\end{array}$ & 75 & $\begin{array}{l}\text { Deskripsi } \\
\text { Sarpras }\end{array}$ \\
\hline Satuan & $\begin{array}{c}\text { VARCH } \\
\text { AR }\end{array}$ & 25 & Satuan \\
\hline ThnBeli & $\begin{array}{c}\text { VARCH } \\
\text { AR }\end{array}$ & 4 & Tahun Beli \\
\hline TglBeli & DATE & - & Tgl. Pembelian \\
\hline HhrgBeli & INT & 3 & Harga Beli \\
\hline JmlBeli & INT & 12 & Jumlah Beli \\
\hline KdJenis & INT & 5 & Kode Jenis \\
\hline KdRuang & INT & 5 & Kode Ruang \\
\hline
\end{tabular}

4) Tabel Mutasi Sarpras

Nama Tabel : Mutasi

Primary Key : IdMutasi

Foreign Key : KdSarpras,KdRuang

Tabel 4. Mutasi Sarpras

\begin{tabular}{|l|c|c|l|}
\hline \multicolumn{1}{|c|}{$\begin{array}{c}\text { Nama } \\
\text { Field }\end{array}$} & Type & $\begin{array}{c}\text { Leba } \\
\mathbf{r}\end{array}$ & Keterangan \\
\hline IdMutasi & Int & 5 & Id Mutasi \\
\hline KdSarpras & INT & 5 & $\begin{array}{l}\text { Kode } \\
\text { Sarpras }\end{array}$ \\
\hline TglMutasi & $\begin{array}{c}\text { VARCH } \\
\text { AR }\end{array}$ & 75 & Tgl. Mutasi \\
\hline KdRuang & INT & 5 & Kd Ruang \\
\hline $\begin{array}{l}\text { AlasanMut } \\
\text { asi }\end{array}$ & $\begin{array}{c}\text { VARCH } \\
\text { AR }\end{array}$ & 75 & Alasan \\
\hline
\end{tabular}

5) Tabel Pengelolaan Sarpras

Nama Tabel : KelolaSarpras

Primary Key : IdKelola

Foreign Key : KdRuang,KdSarpras, KdJenis

Tabel 5. Pengelolaan Sarpras

\begin{tabular}{|c|c|c|c|}
\hline Nama Field & Type & $\begin{array}{l}\text { Leb } \\
\text { ar }\end{array}$ & $\begin{array}{l}\text { Keteranga } \\
\mathbf{n}\end{array}$ \\
\hline IdKelola & INT & 5 & $\begin{array}{l}\text { Id } \\
\text { Pengelolaa } \\
\text { n }\end{array}$ \\
\hline KdRuang & INT & 5 & $\begin{array}{l}\text { Kode } \\
\text { Ruang }\end{array}$ \\
\hline KdSarpras & INT & 5 & $\begin{array}{l}\text { Kode } \\
\text { Sarpras }\end{array}$ \\
\hline KdJenis & $\begin{array}{c}\text { VARCH } \\
\text { AR }\end{array}$ & 5 & Kode jenis \\
\hline NoInventaris & $\begin{array}{c}\text { VARCH } \\
\text { AR }\end{array}$ & 20 & $\begin{array}{l}\text { No } \\
\text { Inventaris }\end{array}$ \\
\hline $\begin{array}{l}\text { TglSerahTer } \\
\text { ima }\end{array}$ & DATE & - & $\begin{array}{l}\text { Tgl } \\
\text { Penyerahan }\end{array}$ \\
\hline NmPetugas & $\begin{array}{c}\text { VARCH } \\
\text { AR }\end{array}$ & 35 & $\begin{array}{l}\text { Nama } \\
\text { Petugas }\end{array}$ \\
\hline Ket & TEXT & - & Keterangan \\
\hline
\end{tabular}

\section{IV.HASIL DAN PEMBAHASAN}

Aplikasi sarana prasarana pendidikan SMKN 4 Kota Bengkulu dibuat dengan menggunakan bahasa pemrograman visual basic. Sementara itu untuk penyimpanan datanya digunakan database mysql.

a. Menu Login Aplikasi

Menu login sistem merupakan menu halaman proses autentikasi pengguna yang akan mengoperasikan aplikasi. Pengguna aplikasi terlebih dahulu harus Login dengan memasukkan username dan password yang benar untuk dapat menuju pada halaman tampilan utama aplikasi. Tampilan login aplikasi seperti terlihat pada gambar 6 . berikut:

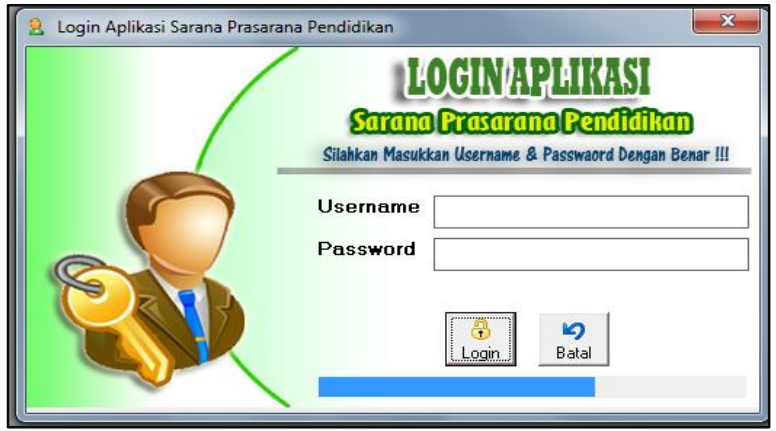

Gambar 6. Login Aplikasi

b. Halaman Utama

Halaman utama aplikasi merupakan halaman yang akan menampilkan secara keseluruhan dari aplikasi 
yang telah dibuat. Tampilan halaman utama seperti terlihat pada gambar 7. berikut:

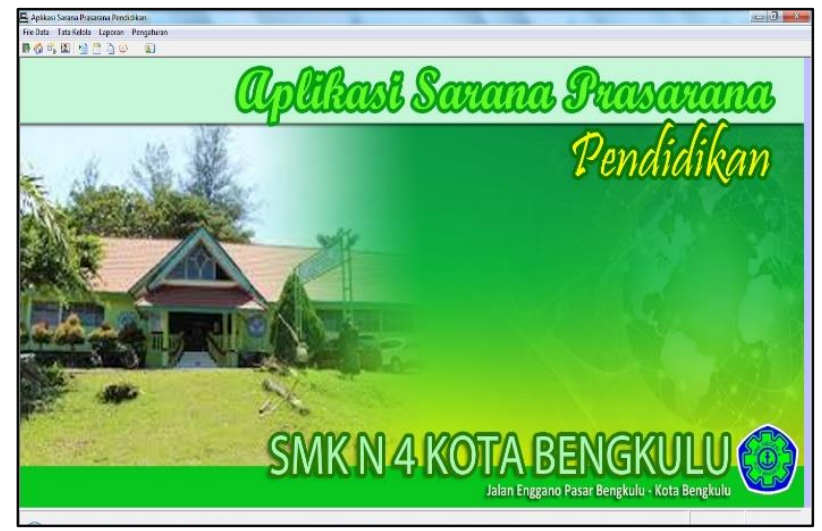

Gambar 7. Halaman Utama Aplikasi

\section{c. Form Input Data Ruang}

Form input data ruang merupakan sub menu yang digunakan untuk memasukkan atau meng-entrikan data-data ruang kedalam aplikasi. Admin dapat menambah, menyimpan, meng-update, menghapus data-data sesuai dengan kebutuhan dengan memiliki pada tombol button yang telah disediakan. Tampilan form input data ruang seperti terlihat pada gambar 8 .

Berikut:

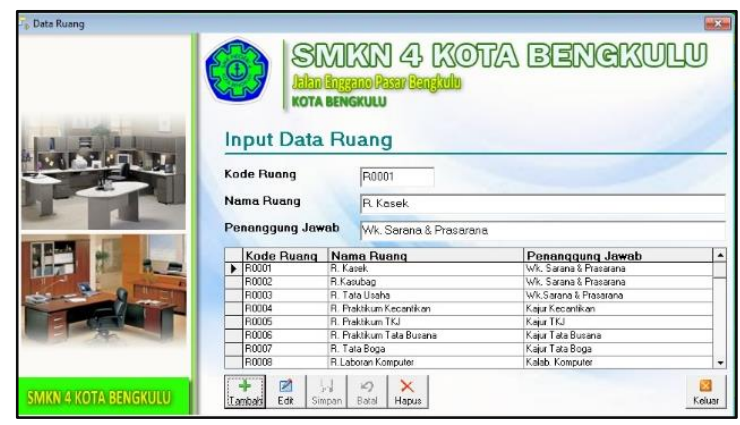

Gambar 8. Form Input Data Ruang

\section{d. Form Input Jenis Sarpras}

Jenis sarana dan prasarana pendidikan pada aplikasi digunakan untuk membedakan apakah barang-barang yang ada pada sekolah masuk dalam kategori jenis sarana atau prasarana. Pada form input data jenis sarpras digunakan untuk memasukkan atau meng-entrikan datadata jenis sarana dan prasarana kedalam aplikasi. Admin dapat menambah, menyimpan, meng-update, menghapus data-data sesuai dengan kebutuhan dengan memiliki pada tombol button yang telah disediakan. Tampilan form input data jenis sarpras seperti terlihat pada gambar 9.berikut:

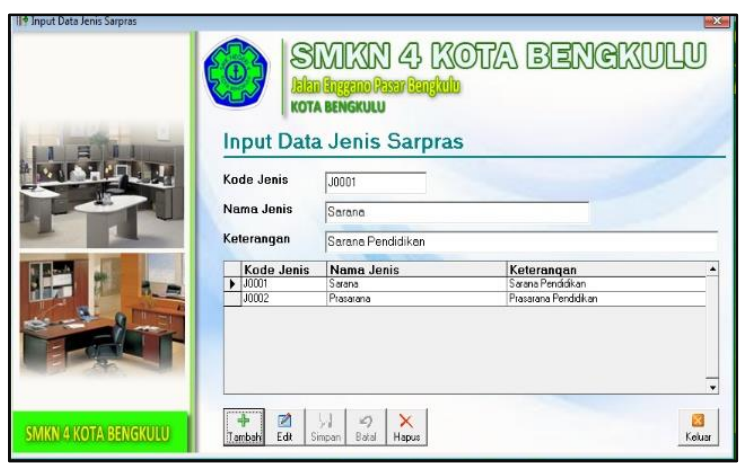

Gambar 9. Form Input Data Jenis Sarpras

\section{e. Form Input Data Sarpras}

Form input data sarana dan prasarana merupakan form yang digunakan untuk memasukkan atau mengentrikan data-data sarana dan prasarana kedalam aplikasi yang telah dibuat. Dalam form ini, seorang admin dapat menambah, menyimpan, meng-update, menghapus data-data sesuai dengan kebutuhan melalui tombol button yang telah disediakan. Tampilan form input data sarpras seperti terlihat pada gambar 10. berikut:

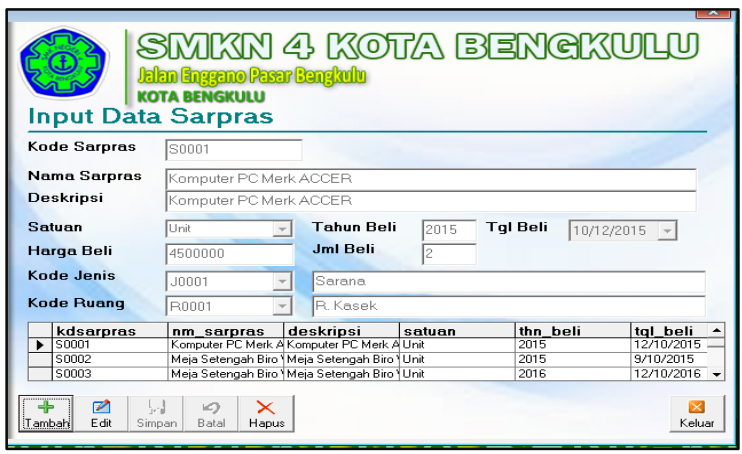

Gambar 10. Form Input Sarana dan Prasarana

\section{f. Form Input Pengelolaan Sarpras}

Form input pengelolaan data sarana dan prasarana digunakan untuk memasukkan atau meng-entrikan data-data sarana dan prasarana kedalam aplikasi yang telah dibuat. Dalam form ini, seorang admin dapat menambah, menyimpan, meng-update, menghapus data-data sesuai dengan kebutuhan melalui tombol button yang telah disediakan. Tampilan form input 
data pengelolaan sarana dan prasarana seperti terlihat pada gambar 11. berikut:

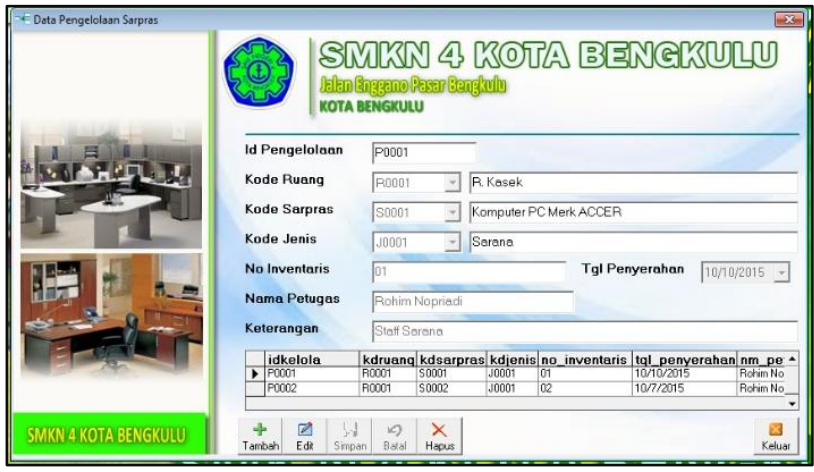

Gambar 11. Form Input Sarana dan Prasarana

\section{g. Menu Laporan}

Menu laporan aplikasi sarana prasarana Pendidikan digunakan untuk mencetak hasil pengolah data-data sarana dan prasarana yang telah diinputkan ke dalam aplikasi dan disesuaikan dengan sesuai kebutuhan

1) Laporan Data Ruang

Laporan data ruang digunakan untuk menampilkan data ruangan yang ada di sekolah, dengan adanya laporan data ruang maka dapat diketahui ruangan apa saja yang dimiliki oleh sekolah. Tampilan laporan data seperti terlihat pada gambar 12 . berikut:

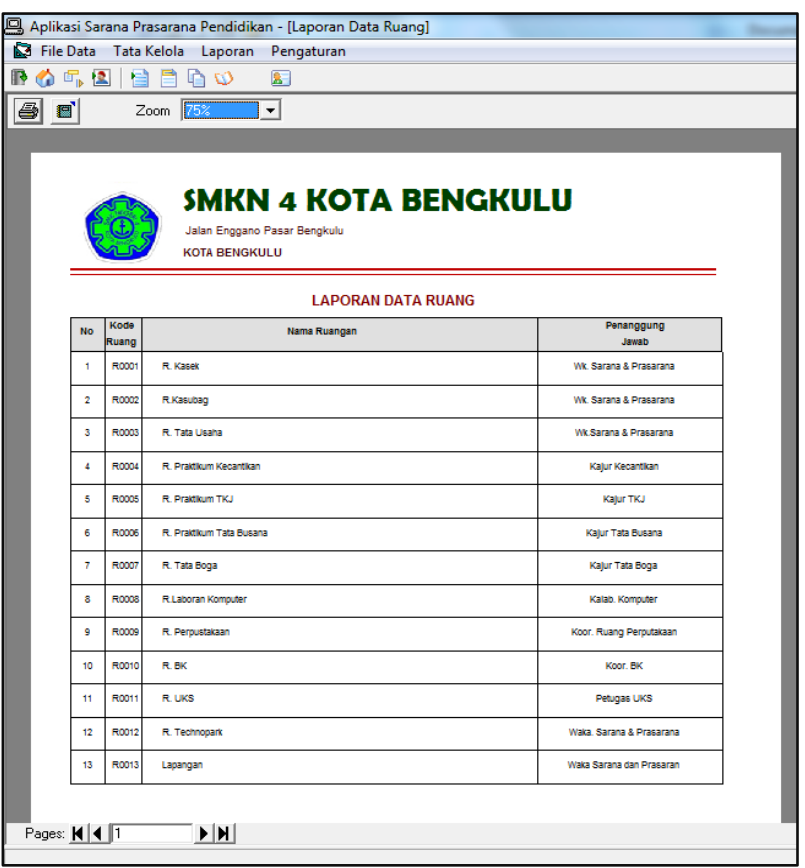

Gambar 12. Laporan Data Ruang
2) Laporan Data Sarana Prasaran Per Ruang

Laporan data sarana prasarana per ruang digunakan untuk menampilkan daftar sarana berdasarkan yang ada di dalam suatu ruang yang ada di sekolah, dengan adanya laporan data sarana dan prasarana per ruang maka dapat diketahui sarana apa saja yang ada dalam ruangan. Tampilan laporan data sarana prasana per ruang seperti terlihat pada gambar 13. Berikut:

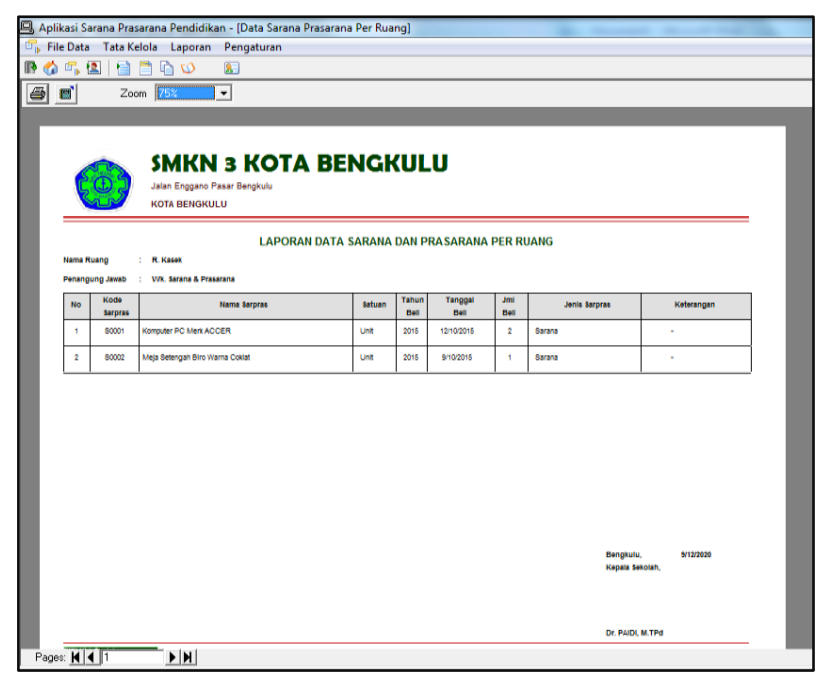

Gambar 13. Laporan Data Sarpras Per Ruang

3) Laporan Sarpras Per Jenis

Laporan sarana dan prasaran per jenis merupakan laporan yang dibuat untuk menampilkan sarana dan prasaran sesuai dengan jenis sarpras yang dimiliki sekolah. Dengan adanya laporan per jenis sararana dan prasarana dapat diketahui sarana dan jenis yang dimiliki oleh sekolah. Tampilan laporan sarana dan prasaran per jenis terlihat pada gambar 14. berikut:

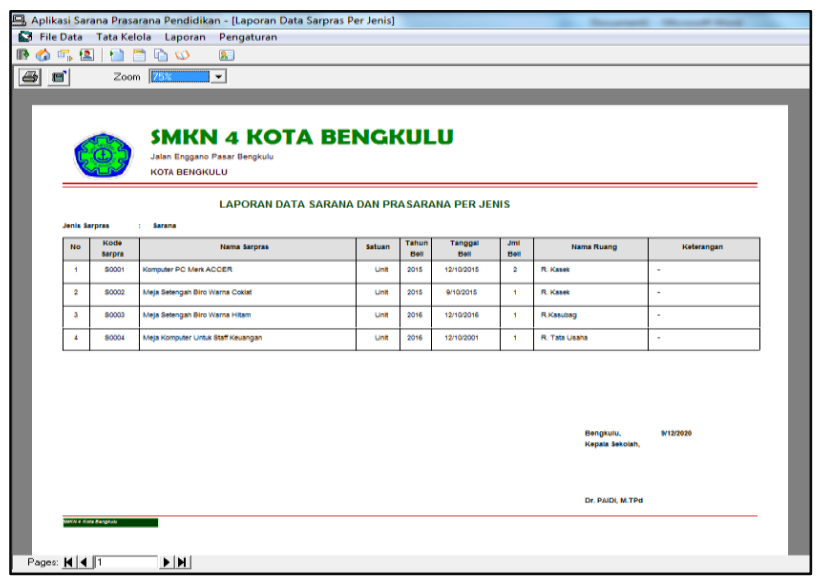

Gambar 14. Laporan Data Sarpras Per Jenis 
4) Rekapitulasi Sarana dan Prasaran Pendidikan

Laporan dalam bentuk rekapitulasi bertujuan untuk mendapatkan informasi secara keseluruhan data-data sarana dan prasarana yang dimiliki oleh sekolah. Tampilan rekapitulasi sarana dan prasarana Pendidikan seperti terlihat pada gambar 15. berikut:

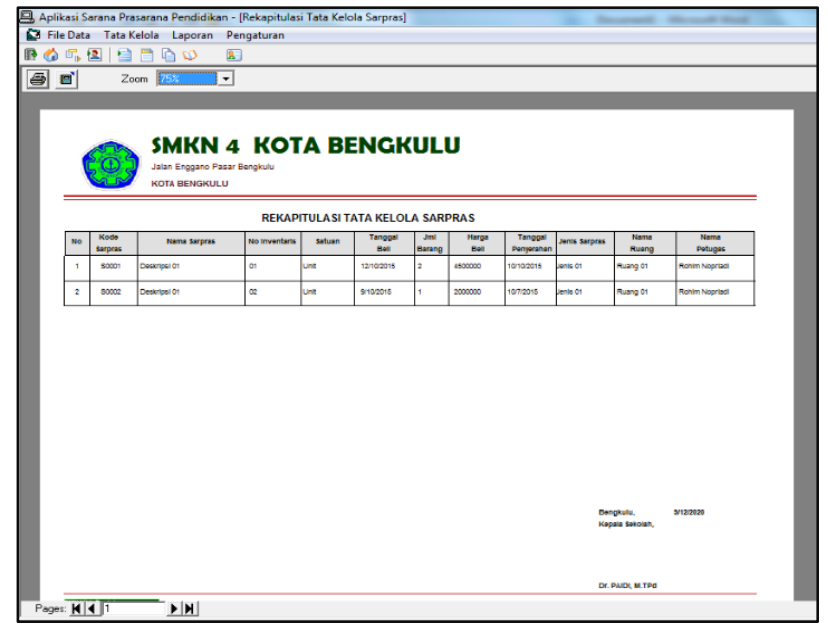

Gambar 15 Rekapitulasi Sarana Prasarana Pendidikan

\section{PENUTUP}

A. Kesimpulan

Aplikasi sarana dan prasarana Pendidikan dibuat dengan bahasa pemrograman visual basic dan database mysql. Pengelolaan data sarana dan prasarana melalui suatu aplikasi khusus dapat membantu kinerja pegawai sehingga data-data yang dapat terdokumentasi dengan baik. Disamping itu, aplikasi yang ada dapat menampilkan laporan-laporan sesuai dengan kebutuhan yang ada di sekolah.

B. Saran

Aplikasi sarana dan prasarana Pendidikan yang telah dibuat diharapkan dapat dipergunakan oleh pihak sekolah dan dapat dilakukan pengembangan lagi sesuai dengan kebutuhan yang ada di sekolah. Disamping itu, adanya operator khusus yang dapat mengoperasikan aplikasi sehingga aplikasi dapat dioperasikan secara maksimal.

\section{DAFTAR PUSTAKA}

[1] Mulyana, E. 2002. Manajemen Berbasis Sekolah: Konsep, Strategi dan Implementasi. Bandung: PT. Remaja Rosdakarya.
[2] Suryosubroto. 2010. Manajemen Pendidikan di Sekolah. Jakarta: Rineka Cipta.

[3] Imron, Ali dan Maisyaroh. 2003. Manajemen Pendidikan: Analisis Subtantif dan Aplikasi Dalam Institusi Pendidikan. Malang: Universitas Negeri Malang.

[4] Qomar, Mujamil. 2002. Manajeman Pendidikan Islam. Malang: Erlangga.

[5] Minarti, Sri. 2011. Manajemen Sekolah: Mengelola Lembaga Pendidikan Secara Mandiri. Yogyakarta: Ar-Ruzz Media.

[6] Kadir, Abdul. 2017. Dasar Logika Pemrograman Komputer Panduan Berbasis Flowchart Menggunakan Flowgorithm. Jakarta: ELex Media Komputindo.

[7] Hengky. 2011. Seri Penuntun Praktis Microsoft Visual Basic, Jakarta: PT. Elex Media Komputindo.

[8] Zaki, Ali. 2008. PHP dan MySQL. Jakarta: Elex Media Komputindo.

[9] Kristanto, Andri. 2007. Perancangan Sistem Informasi dan Aplikasinya. Yogyakarta: Gava Media.

[10] Hanif, Al Fatta. 2007. Analisis dan Perancangan Sistem Informasi Untuk keunggulan Bersaing Perusahaan dan Organisasi Modern. Yogyakarta: Andi Yogyakarta. 